\title{
Petrology of dunite/harzburgite with decimeter-scale stratification in a drill core from the Tari-Misaka ultramafic complex, southwestern Japan
}

\author{
Ichiro Matsumoto*,** and Shoji Arai*** \\ *Dowa Engineering Co., Ltd., 5-10-5 Shimbashi, Minato-ku, \\ Tokyo 105-0004, Japan \\ **Present address: Department of Earth Sciences, Faculty of Education Shimane University, \\ Nishikawatsu, Matsue 690-8504, Japan \\ ***Department of Earth Sciences, Kanazawa University, \\ Kakuma, Kanazawa 920-1192, Japan
}

\begin{abstract}
A drill core from Tari-Misaka ultramafic complex, southwestern Japan, shows a one meter interval in which a decimeter scale stratification of dunite/harzburgite is well preserved. This part was petrologicaly examined in detail. Special attention was focused on the morphology and chemistry of chromian spinel. Chromian spinel is more abundant, more euhedral and higher in $\mathrm{Ti}$ and $\mathrm{Fe}^{3+}$ contents, and slightly lower in $\mathrm{Cr} /(\mathrm{Cr}+\mathrm{Al})$ ratio in dunite than in harzburgite. Harzburgite becomes orthopyroxene-poor, and its chromian spinel tends to be similar to dunite spinel near (usually within $5 \mathrm{~cm}$ ) the lithological between dunite. It was presumed that the dunite was formed as veins as a result of a reaction between harzburgite and an exotic melt: olivine crystals was formed by a reaction between hartzbergite and the melt.

The petrological and chemical features of this part of the drill is basically similar to those in dunite with large chromitite pods, and harzburgite widely distributed in the Wakamatsu mine area. It is suggested that the dunites within harzburgite have the same origin irrespective of their dimension and the presence of chromite pods or not. The lower $\mathrm{Cr} \#$ of spinel in the drill-core rocks than those in widely distributed dunite is possibly due to the difference in amount of orthopyroxene reacted with the melt. A large amount of orthopyroxene reacted and turbulency of melt current may be indispensable for the formation of podiform chromitite. The large melt conduit represented by dunite of semi-regional distribution in the Wakamatsu mine area possibly fulfilled the all of the conditions for the formation through this process of chromitite pods.
\end{abstract}

\section{Introduction}

Secondary dunite is formed within harzburgite in various scales in the upper mantle. Quick (1981) and Kelemen (1990) among others demonstrated the importance of dunite as a reaction product between melt and peridotite. The dunite replacing peridotite, especially harzburgite, sometimes accompanies syngenetic podiform chromitite in its central part (e.g., Lago et al., 1982). Its genesis is thus related to the dunite formation. The

I. Matsumoto, 松本一郎, chromim @edu.shimane-u.ac.jp Corresponding author

S. Arai, 荒井章司, ultrasa@ kenroku.kanazawa-u.ac.jp concentration of spinel to form podiform chromitites has been explained by the process of magma/peridotite reaction (e.g., Arai and Yurimoto, 1992, 1994; Arai, 1997). Detailed studies on dunite/harzburgite pairs of various dimensions, and with or without chromitite association, are very important to clarify the processes not only for dunite formation within harzburgite but also of spinel concentration within the dunite.

In this article we describe a decimeter-scale dunite/ harzburgite alternation observed from a drill core sample 5MADO-2 obtained by Ministry of International Trade and Industry (MITI) (MITI, 1994) near the Wakamatsu chromite mine of the Tari-Misaka ultramafic complex, southwestern Japan (Fig. 1). The Tari-Misaka peridotite complex, southwestern Japan, 

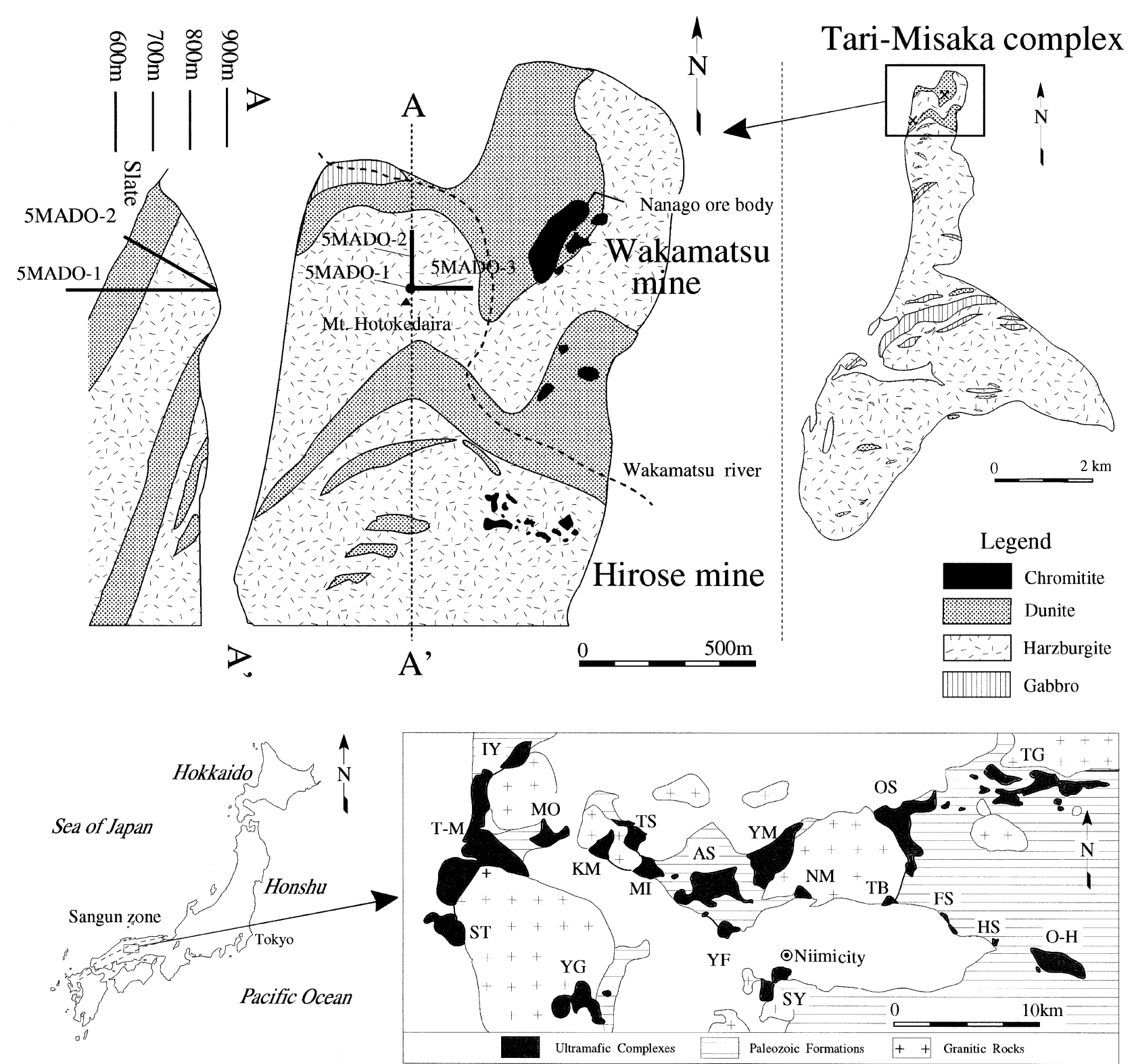

Figure 1. Geological sketch map of the Tari-Misaka ultramafic complex. After MITI (1994) and Matsumoto et al. (1995). ST, Siratakiyama; T-M, Tari-Misaka; IY, Inazumiyama; MO, Mochimaru; YG, Yagami; KM, Kasamatsu; TS, Takase; MI, Mimuro; AS, Ashidachi; YF, Yufune; YM, Yanomine; SY, Suishoyama; NM, Niimi; OS, Osa; TB, Tajibe; FS, Fuse; TG, Taguchi; HS, Harashige; and $\mathrm{O}-\mathrm{H}$, Ochiai Hokubo complexes. Note that the chromitite pods of the northern part of the TariMisaka complex are projected in plan.

has large-scale dunite layers up to $100 \mathrm{~m}$ thick, which frequently contain large chromitite pods up to $20 \mathrm{~m}$ thick, in harzburgite (e.g., Arai, 1980; Matsumoto and Arai, 2001). We also try to make a comparison between the two types of dunite, one is thick and is associated with appreciable chromitite pods and the other, far smaller in dimension present in the drill core.

\section{Geological background}

Many ultramafic complexes are distributed in the San- gun zone of the central Chugoku district, (Fig. 1), and are interpreted as thin slices piled up by thrusts (e.g., Ishiwatari, 1991). All of the ultramafic complexes except the Ochiai-Hokubo complex (e.g., Arai et al., 1988) are composed of serpentinized peridotites (harzburgite and dunite) and small amounts of chromitite (Arai, 1980; Matsumoto et al., 1995). Harzburgite is always dominant over dunite in this zone. They are frequently covered with Cretaceous volcanic rocks and are intruded by Cretaceous granitic rocks. The contact aureole between harzburgite and granite is well devel- 
oped. Five mineral zones are observed in the ultramafic complexes: chrysotile-lizardite (unmetamorphosed) (Ia), antigorite (Ib), olivine-talc (II), olivineanthophyllite (III) and olivine-orthopyroxene (IV) enumerated in the order of increasing metamorphic temperature (Arai, 1975; Matsumoto et al., 1995).

The Tari-Misaka ultramafic complex, located at the west end of the zone constitutes the ultramafic complexes of the central Chugoku district. The complex has two large chromite mines at Wakamatsu and Hirose. This area has been the largest chromite field in Japan, but all the mines are now closed or abandoned. They are located in the northern part of the complex, where dunite is relatively dominant and roughly layered with harzburgite (Hirano et al., 1978; Matsumoto et al., 1995; Matsumoto and Arai, 1997). In contrast to this, harzburgite is always far dominant over dunite in the remaining part of the Tari-Misaka complex (Matsumoto et al., 1997).

Many chromitite pods are distributed in the area of the Wakamatsu and Hirose mines. The largest chromitite pod is the "Nanago ore body" in the Wakamatsu mine and is $20 \mathrm{~m}$ thick, $30 \mathrm{~m}$ wide and $200 \mathrm{~m}$ long in size.

\section{Description of decimeter-scale dunite/harzburgite stratification, at an interval from 147.8 to $148.8 \mathrm{~m}$ of the core 5MADO-2}

\section{General remarks}

Three drilling were performed by the Metal Mining Agency of Japan (MMAJ) at the summit of Mt. Hotokedaira (MITI, 1994) situated at the northern part of the complex (Fig. 1), in order to explore chromitite reserves. The site corresponds to the harzburgite-dominant portion around the mine (Fig. 1). The three holes, 5MADO-1, 5MADO-2 and 5MADO-3 have different dips, vertical, $30^{\circ}$ north and $30^{\circ}$ east, respectively, against the bottom of the ultramafics. The recovered cores are $4.7 \mathrm{~cm}$ in diameter and represent $>99 \%$ of the body. The dip angles of lithological boundaries observed vary from 15 to $30^{\circ}$ in the cores.

\section{Petrography}

The drill site is located in Zone II (olivine-talc zone) of the contact aureole. Primary silicate minerals are hardly recognized. In addition to the thermal metamorphism, the rocks are severely serpentinized. Aggregates of talc and magnetite are most probably peudomorphs after orthopyroxene. The aggregates are very similar in
5MADO-1 5MADO-2 5MADO-3

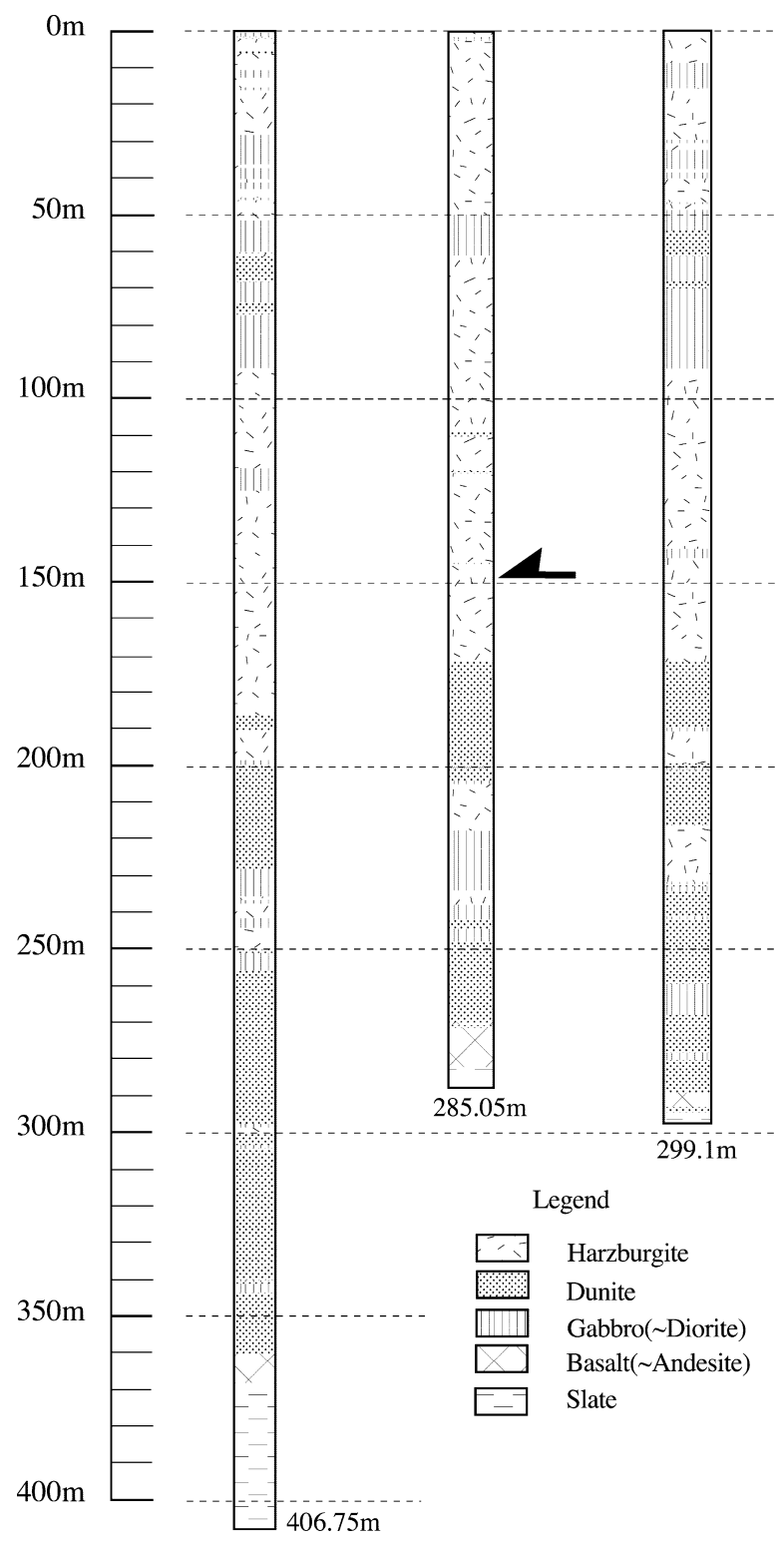

Figure 2. Lithological columns of the drill cores, 5MADO-1, 5MADO-2 and 5MADO-3 from the northern part of the Tari-Misaka complex (Fig. 1). Note that harzburgite and dunite are predominant in the upper and lower part, respectively, of the cores.

shape, size and abundance resemble to primary orthopyroxene in unmetamorphosed harzburgite exposed in Zone Ia around Misaka to the south of the mine. The aggregates of the same kind with relic orthopyroxene are commonly found from Zone II of the other complexes of the Sangun zone. Judging from the presence of trace amount of tremolite, a small amount of primary clinopyroxene may have been present originally. Original harzburgite and dunite can be easily distinguished by the amount of the pseudomorphs after orthopyroxene. 


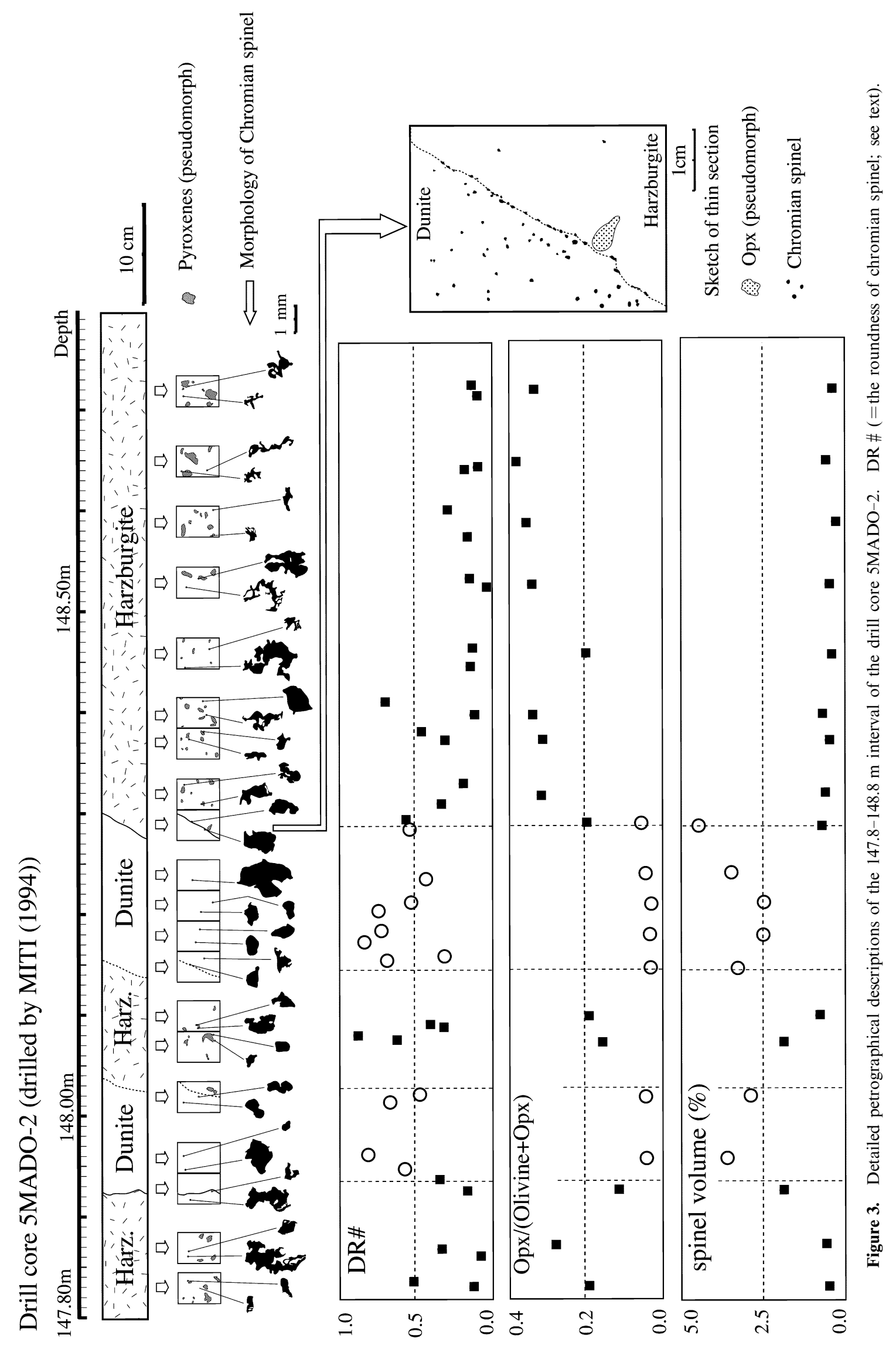



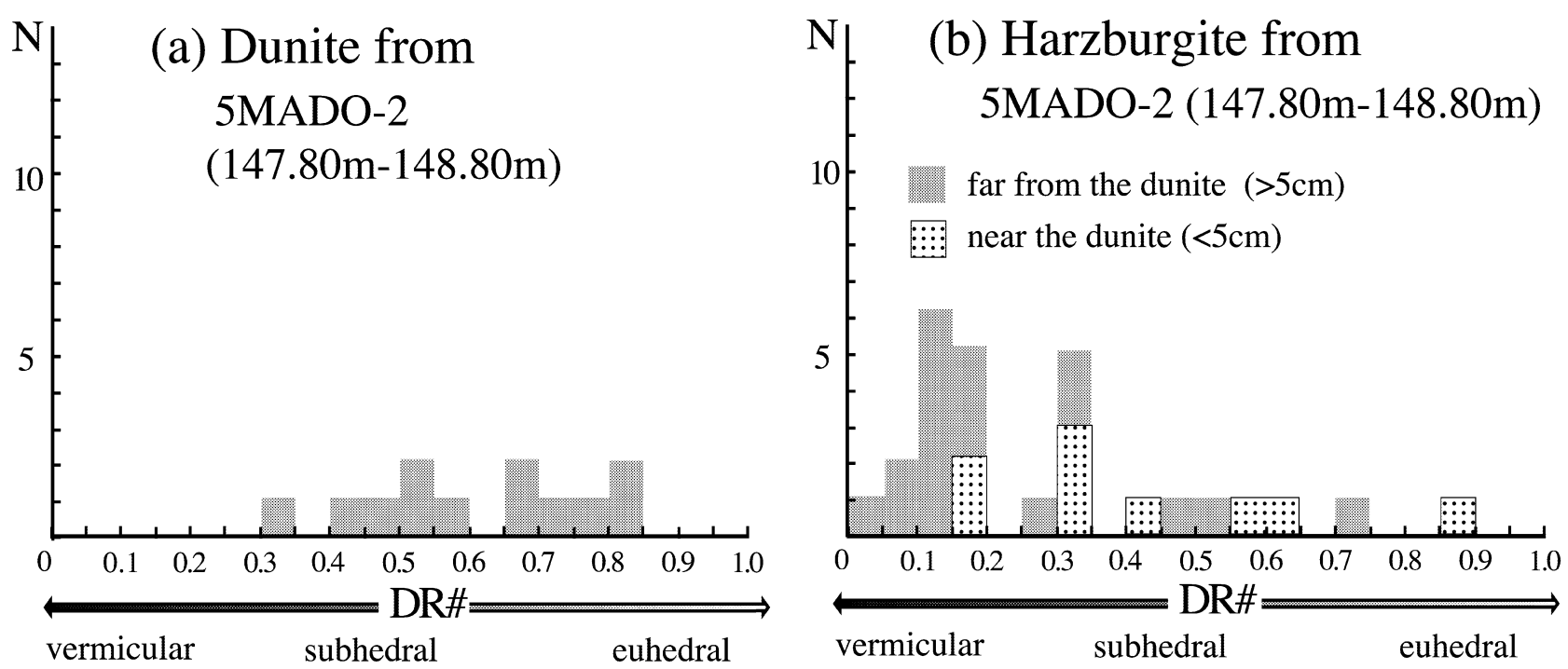

\section{(c) Dunite}

\section{Sangun-zone complexes}

Wakamatsu mine area

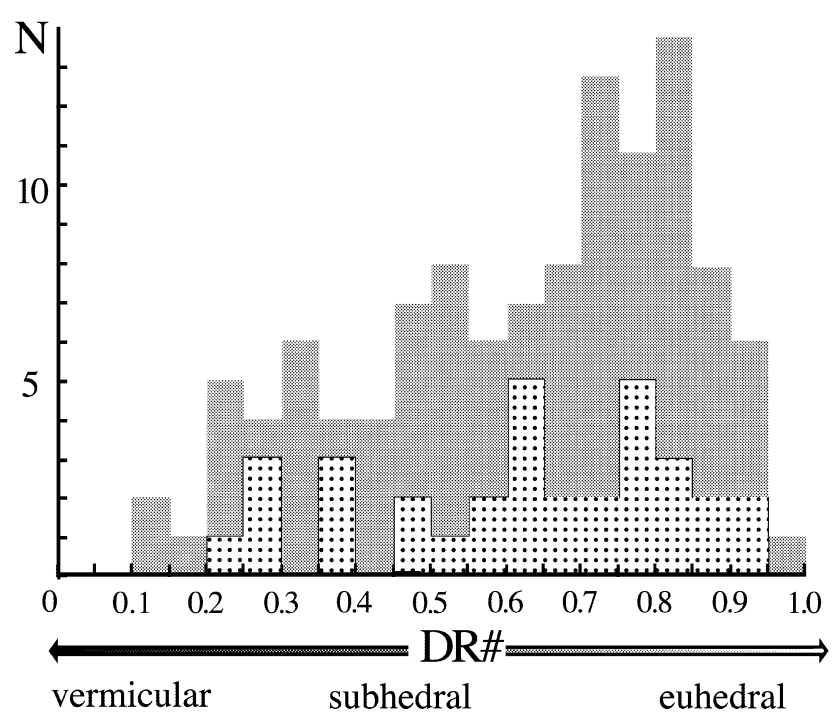

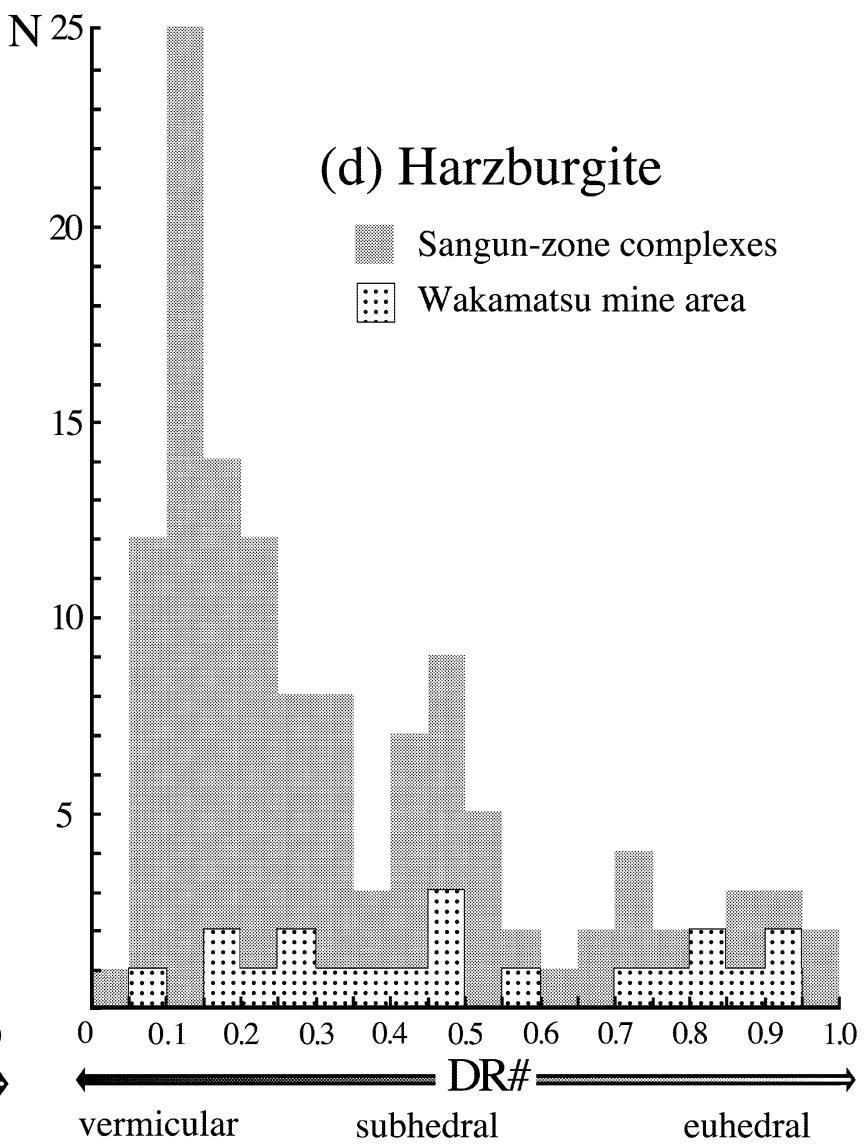

Figure 4. Frequency histograms of the DR \# of chromian spinel in ultramafic rocks from the Sangun zone. (a) and (b), dunite and harzburgite, respectively, from the 147.8-148.8 m interval of the drill core 5MADO-2. (c) and (d), dunite and harzburgite, respectively, from the Sangun zone (Matsumoto, 1995; Matsumoto and Arai, 1997). Black part is from all ultramafic complexes shown in Figure 1 except the $\mathrm{O}-\mathrm{H}$ complex. Grey part is from the Wakamatsu mine.

In contrast to the primary silicates, chromian spinel is resistant against the metamorphism and serpentinization, and chemically intact cores are often preserved.

The drill cores are mainly composed of harzburgite and dunite (Fig. 2). Harzburgite is far dominant from the surface to about $150 \mathrm{~m}$ downhole in each core. Dunite became dominant in deeper parts. Small micro gabbroic or dioritic intrusive with chilled margins are in 
Table 1. Selected microprobe analyses of chromian spinels in the ultramafic rocks

\begin{tabular}{|c|c|c|c|c|c|c|c|c|}
\hline & \multicolumn{4}{|c|}{ Harzburgite (near the dunite) } & \multicolumn{4}{|c|}{ Harzburgite (far from the dunite) } \\
\hline & $\begin{array}{r}5 \mathrm{MADO} 2- \\
147.87 \mathrm{~m} \\
\end{array}$ & $\begin{array}{r}5 \mathrm{MADO} 2- \\
148.07 \mathrm{~m} \\
\end{array}$ & $\begin{array}{r}5 \mathrm{MADO} 2- \\
148.10 \mathrm{~m} \\
\end{array}$ & $\begin{array}{r}5 \mathrm{MADO} 2- \\
148.32 \mathrm{~m} \\
\end{array}$ & $\begin{array}{r}5 \mathrm{MADO} 2- \\
148.53 \mathrm{~m} \\
\end{array}$ & $\begin{array}{r}5 \mathrm{MADO} 2- \\
148.59 \mathrm{~m} \\
\end{array}$ & $\begin{array}{r}5 \mathrm{MADO} 2- \\
148.65 \mathrm{~m} \\
\end{array}$ & $\begin{array}{r}5 \mathrm{MADO} 2- \\
148.72 \mathrm{~m} \\
\end{array}$ \\
\hline $\mathrm{TiO}_{2}$ & 0.19 & 0.23 & 0.22 & 0.13 & 0.14 & 0.10 & 0.08 & 0.11 \\
\hline $\mathrm{Al}_{2} \mathrm{O}_{3}$ & 26.22 & 28.12 & 27.50 & 30.31 & 28.09 & 28.65 & 28.86 & 28.75 \\
\hline $\mathrm{Cr}_{2} \mathrm{O}_{3}$ & 42.23 & 35.86 & 39.00 & 37.93 & 40.31 & 39.88 & 39.21 & 40.08 \\
\hline $\mathrm{FeO} *$ & 16.93 & 21.11 & 17.08 & 16.70 & 16.69 & 18.12 & 18.51 & 17.73 \\
\hline $\mathrm{MnO}$ & 0.24 & 0.26 & 0.24 & 0.24 & 0.23 & 0.26 & 0.24 & 0.23 \\
\hline $\mathrm{MgO}$ & 13.76 & 13.41 & 13.79 & 13.91 & 13.85 & 12.94 & 12.99 & 13.17 \\
\hline $\mathrm{V}_{2} \mathrm{O}_{3}$ & 0.22 & 0.16 & 0.16 & 0.19 & 0.17 & 0.19 & 0.17 & 0.15 \\
\hline TOTAL & 99.79 & 99.15 & 97.99 & 99.41 & 99.48 & 100.14 & 100.06 & 100.22 \\
\hline $\mathrm{O}$ & 4 & 4 & 4 & 4 & 4 & 4 & 4 & 4 \\
\hline $\mathrm{Ti}$ & 0.004 & 0.005 & 0.005 & 0.003 & 0.003 & 0.002 & 0.002 & 0.003 \\
\hline $\mathrm{Al}$ & 0.931 & 0.996 & 0.973 & 1.064 & 0.994 & 1.012 & 1.020 & 1.013 \\
\hline $\mathrm{Cr}$ & 1.006 & 0.852 & 0.926 & 0.893 & 0.957 & 0.945 & 0.929 & 0.948 \\
\hline $\mathrm{Fe}$ & 0.429 & 0.536 & 0.469 & 0.413 & 0.416 & 0.450 & 0.460 & 0.440 \\
\hline $\mathrm{Mn}$ & 0.006 & 0.007 & 0.006 & 0.006 & 0.006 & 0.007 & 0.006 & 0.006 \\
\hline $\mathrm{Mg}$ & 0.618 & 0.601 & 0.617 & 0.617 & 0.620 & 0.578 & 0.580 & 0.587 \\
\hline V & 0.005 & 0.004 & 0.004 & 0.005 & 0.004 & 0.005 & 0.004 & 0.004 \\
\hline TOTAL & 3.000 & 3.000 & 3.000 & 3.000 & 3.000 & 3.000 & 3.000 & 3.000 \\
\hline $\mathrm{Cr} \#$ & 0.519 & 0.461 & 0.488 & 0.456 & 0.491 & 0.483 & 0.477 & 0.483 \\
\hline $\mathrm{Fe}^{3+} \#$ & 0.024 & 0.069 & 0.044 & 0.016 & 0.02 & 0.017 & 0.022 & 0.015 \\
\hline Mg\# & 0.619 & 0.602 & 0.618 & 0.619 & 0.622 & 0.581 & 0.583 & 0.589 \\
\hline DR\# & 0.34 & 0.886 & 0.55 & 0.34 & 0.155 & 0.166 & 0.181 & 0.103 \\
\hline spinel mode & 0.6 & 1.9 & 0.7 & 0.6 & 0.5 & 0.3 & 0.6 & 0.4 \\
\hline $\mathrm{Op} /(\mathrm{Op}+\mathrm{Ol})$ & 0.284 & 0.157 & 0.200 & 0.319 & 0.343 & 0.357 & 0.383 & 0.337 \\
\hline
\end{tabular}

$\mathrm{FeO}^{*}$, total iron as $\mathrm{FeO} . \quad$ Cation fractions in spinel were calculated assuming spinel stoichiometry. $\mathrm{Cr} \#, \mathrm{Cr} /(\mathrm{Cr}+\mathrm{Al})$ atomic ratio;

the area. (Fig. 2). A basaltic dike is observed between the ultramafic rocks and basement slate (Fig. 2).

A one-meter interval (147.8 to $148.8 \mathrm{~m}$ ) of the drill core $5 \mathrm{MADO}-2$, demonstrates the fine-scale stratification (alternation) of dunite and harzburgite (Fig. 3). Two dunite parts are found within harzburgite at intervals from 147.9 to $148.0 \mathrm{~m}$ and 148.2 to $148.3 \mathrm{~m}$ (Fig. 3). Each dunite part is about $10 \mathrm{~cm}$ in thickness, and the boundaries with harzburgite are relatively sharp.

Harzburgite possibly had a protogranular texture. The orthopyroxene/(olivine+ orthopyroxene) ratio in harzburgite is relatively low near the dunite, and is very low in a thin harzburgite part between dunite parts (around $148.1 \mathrm{~m}$ in depth) (Fig. 3). Spinel is relatively abundant in dunite, 3.0 vol\% in average (from 1.9 to $4.5 \%)$ and very sparse in harzburgite, $0.65 \mathrm{vol} \%$ in average (from 0.30 to $1.90 \%$ ). The amount of spinel tends to be high in harzburgite near dunite (Fig. 3). The chromian spinel is increased in amount in dunite part of the $148.2-148.3 \mathrm{~m}$ interval towards the harzburgite boundaries (Fig. 3). The morphology of chromian spinel is variable, but tends to be anhedral in harzburgite and euhedral in dunite.

\section{Spinel morphology}

Matsumoto (1995) defined DR \# (= degree of roundness) in order to describe quantitatively the morphology of chromian spinel. The DR\# is defined as area/ (round length $)^{2}$ that is normalized by the value of a circle $(1 /(4 \pi)=0.0796)$ (Matsumoto, 1995). The DR \# of chromian spinel in peridotites from the Sangun zone exhibits large variations from dunite to harzburgite (Matsumoto, 1995; Matsumoto and Arai, 1997, 2001) (Fig. 4). The DR \# is usually $<0.4$ (anhedral to vermicular) in harzburgite but is usually $>0.4$ (euhedral to subhedral) and most frequently 0.7 to 0.9 (euhedral) in dunite (Fig. 4).

In the 147.8-148.8 $\mathrm{m}$ interval of the drill core $5 \mathrm{MADO}-2$, the DR \# of spinel in harzburgite is 0.30 in average (from 0.89 to 0.04 ) and 0.57 (from 0.84 to 0.17 ) in dunite (Figs. 3 and 4; Table 1).

\section{Spinel chemistry}

Primary spinels from the interval $(147.8-148.8 \mathrm{~m})$ of the drill core 5MADO-2 were analyzed by microprobeJCMA733MkII with wavelength dispersive 
in the one-meter interval (147.8 to $148.8 \mathrm{~m}$ ) from the drilled core 5MADO-2

\begin{tabular}{|c|c|c|c|c|c|c|}
\hline & $\begin{array}{r}5 \mathrm{MADO} 2- \\
147.93 \mathrm{~m} \\
\end{array}$ & $\begin{array}{r}5 \mathrm{MADO}- \\
147.96 \mathrm{~m} \\
\end{array}$ & $\begin{array}{c}\text { Dunite } \\
5 \mathrm{MADO} 2- \\
148.02 \mathrm{~m} \\
\end{array}$ & $\begin{array}{r}5 \mathrm{MADO} 2- \\
148.18 \mathrm{~m} \\
\end{array}$ & $\begin{array}{r}5 \mathrm{MADO} 2- \\
148.21 \mathrm{~m} \\
\end{array}$ & $\begin{array}{r}5 \mathrm{MADO} 2- \\
148.29 \mathrm{~m} \\
\end{array}$ \\
\hline $\mathrm{TiO}_{2}$ & 0.25 & 0.24 & 0.28 & 0.23 & 0.23 & 0.22 \\
\hline $\mathrm{Al}_{2} \mathrm{O}_{3}$ & 28.66 & 28.69 & 28.40 & 28.52 & 28.84 & 28.92 \\
\hline $\mathrm{Cr}_{2} \mathrm{O}_{3}$ & 36.18 & 35.59 & 37.13 & 35.99 & 36.14 & 38.05 \\
\hline $\mathrm{FeO}^{*}$ & 21.40 & 21.00 & 20.64 & 20.71 & 21.06 & 18.34 \\
\hline $\mathrm{MnO}$ & 0.25 & 0.25 & 0.27 & 0.25 & 0.25 & 0.23 \\
\hline $\mathrm{MgO}$ & 13.63 & 13.79 & 13.03 & 13.45 & 13.42 & 13.98 \\
\hline $\mathrm{V}_{2} \mathrm{O}_{3}$ & 0.18 & 0.16 & 0.18 & 0.17 & 0.20 & 0.16 \\
\hline TOTAL & 100.55 & 99.72 & 99.93 & 99.32 & 100.14 & 99.90 \\
\hline $\mathrm{O}$ & 4 & 4 & 4 & 4 & 4 & 4 \\
\hline $\mathrm{Ti}$ & 0.006 & 0.005 & 0.006 & 0.005 & 0.005 & 0.005 \\
\hline $\mathrm{Al}$ & 1.007 & 1.012 & 1.007 & 1.013 & 1.017 & 1.017 \\
\hline $\mathrm{Cr}$ & 0.853 & 0.842 & 0.883 & 0.858 & 0.855 & 0.897 \\
\hline $\mathrm{Fe}$ & 0.519 & 0.516 & 0.509 & 0.510 & 0.515 & 0.450 \\
\hline $\mathrm{Mn}$ & 0.006 & 0.006 & 0.007 & 0.006 & 0.006 & 0.006 \\
\hline $\mathrm{Mg}$ & 0.605 & 0.615 & 0.584 & 0.604 & 0.598 & 0.622 \\
\hline V & 0.004 & 0.004 & 0.004 & U.UU4 & 0.005 & 0.004 \\
\hline TOTAL & 3.000 & 3.000 & 3.000 & 3.000 & 3.001 & 3.001 \\
\hline $\mathrm{Cr} \#$ & 0.459 & 0.454 & 0.467 & 0.458 & 0.457 & 0.469 \\
\hline $\mathrm{Fe}^{3+} \#$ & 0.063 & 0.067 & 0.047 & 0.058 & 0.057 & 0.036 \\
\hline Mg\# & 0.606 & 0.615 & 0.584 & 0.605 & 0.599 & 0.622 \\
\hline DR\# & 0.347 & 0.817 & 0.675 & 0.843 & 0.538 & 0.543 \\
\hline spinel mode & 1.9 & 3.6 & 2.9 & 2.5 & 2.5 & 4.5 \\
\hline $\mathrm{Op} /(\mathrm{Op}+\mathrm{Ol})$ & 0.116 & 0.055 & 0.038 & 0.025 & 0.023 & 0.047 \\
\hline
\end{tabular}

$\mathrm{Fe}^{3+} \#, \mathrm{Fe}^{3+} /\left(\mathrm{Cr}+\mathrm{Al}+\mathrm{Fe}^{3+}\right)$ atomic ratio; $\mathrm{Mg} \#, \mathrm{Mg} /\left(\mathrm{Mg}+\mathrm{Fe}^{2+}\right)$ atomic ratio.

spectrometers at the University of Tokyo and by SEM (Akashi alpha-30A) with an energy dispersive spectrometer at Kanazawa University. Selected analyses are listed in Table 1.

The $\mathrm{Cr} \#(=\mathrm{Cr} /(\mathrm{Cr}+\mathrm{Al})$ atomic ratio $)$ of chromian spinel varies from 0.45 to 0.51 ( 0.46 in average) in dunite and from 0.44 to 0.53 ( 0.48 in average) in harzburgite (Figs. 4 and 5). It is noteworthy that the $\mathrm{Cr} \#$ of spinel is slightly higher in harzburgite than in dunite (Fig. 5c). The $\mathrm{TiO}_{2}$ content (wt\%) varies from 0.19 to $0.28(0.24$ in average) in dunite and from 0.08 to 0.23 (0.14 in average) in harzburgite (Fig. 5c). The $\mathrm{Fe}^{3+} \#\left(=\mathrm{Fe}^{3+} /(\mathrm{Cr}+\mathrm{Al}+\right.$ $\mathrm{Fe}^{3+}$ ) atomic ratio) varies from 0.035 to 0.067 (average $=$ 0.06 ) in dunite and from 0.015 to 0.069 (average $=0.02$ ) in harzburgite (Fig. 5c). The $\mathrm{TiO}_{2}$ content and $\mathrm{Fe}^{3+} \#$ of spinel are higher in dunite than in harzburgite. The $\mathrm{V}_{2} \mathrm{O}_{3}$ content (wt\%) of spinel is almost the same in dunite and harzburgite, 0.17 in average in dunite and 0.18 in average in harzburgite (Fig. 5c). The compositional range of spinel from the interval is almost the same as that in the other parts of the drill cores (5MADO-1, -2 and -3 ; MITI, 1994).

\section{Discussion and implications}

The chemical characteristics, relatively low $\mathrm{Cr} \#$ and the high $\mathrm{TiO}_{2}$ content and $\mathrm{Fe}^{3+} \#$ (Fig. 5c), of spinel in dunite are not consistent with the residual origin of the dunite from harzburgite. This may suggest an intrusion of exotic melt to form the dunite. The melt may have been relatively high in $\mathrm{TiO}_{2}$ and $\mathrm{Fe}^{3+}$ contents and low in $\mathrm{Cr} \#$, not in equilibrium with the surrounding harzburgite minerals. The dunite is most probably a product of the reaction between the melt and wall harzburgite, that is, the precipitation of olivine combined with decomposition of orthopyroxene of harzburgite. The decomposition of orthopyroxene may be suggested by relatively small amounts of orthopyroxene in harzburgite close to the boundaries with dunite (Fig. 3). The small spinel concentration along the dunite margin (the 148.15-148.28 m interval) (Fig. 3) may mean an effect of magma mixing as an embryo of podiform chromitite (cf., Arai and Abe, 1995). The chromian spinel modified by the melt in the wall of harzburgite, are showing the lowering of $\mathrm{Cr} \#$ and enhancement of $\mathrm{DR} \#, \mathrm{TiO}_{2}$ content and $\mathrm{Fe}^{3+}$ ratio (Figs. 3 and 5c). The place where 
(a)

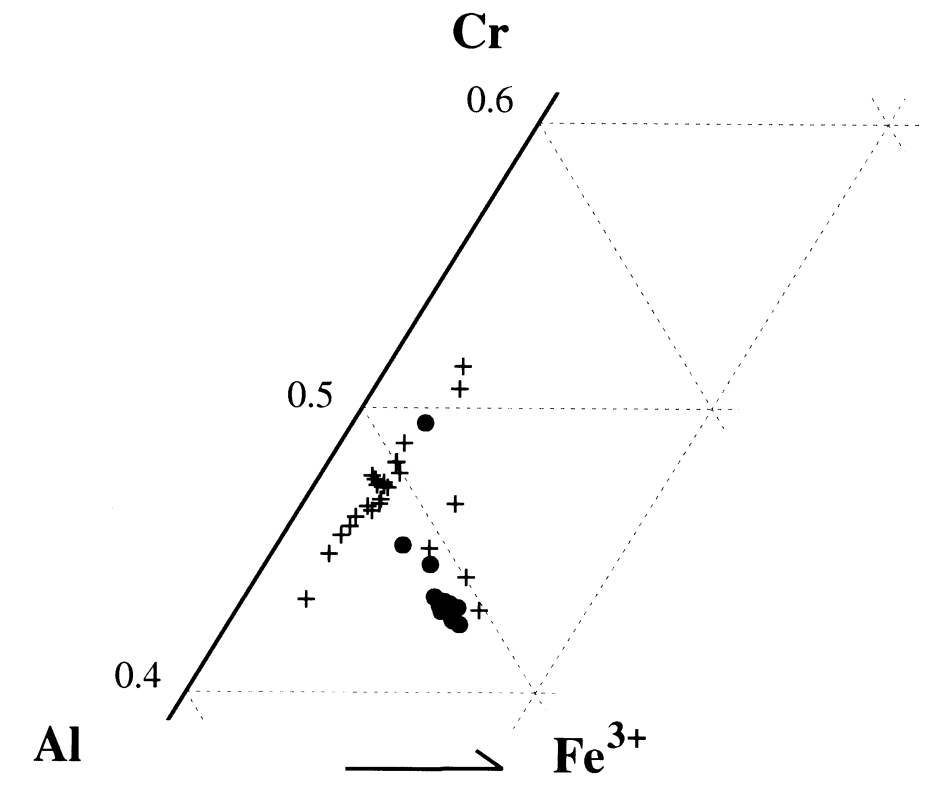

(b)

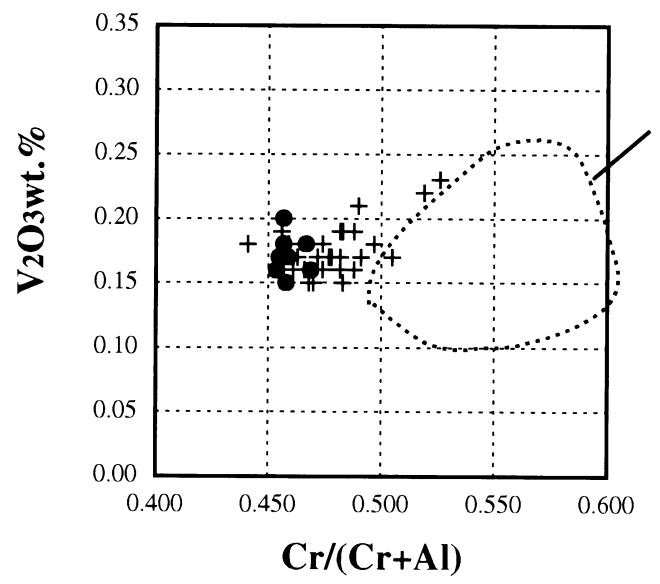

Wakamatsu mine (see Matsumoto and Arai, 1997).

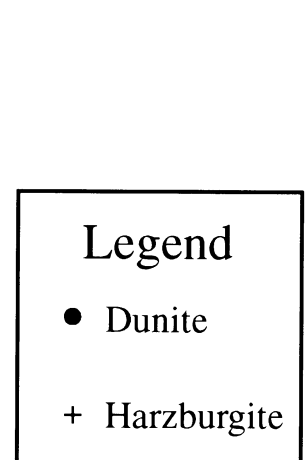

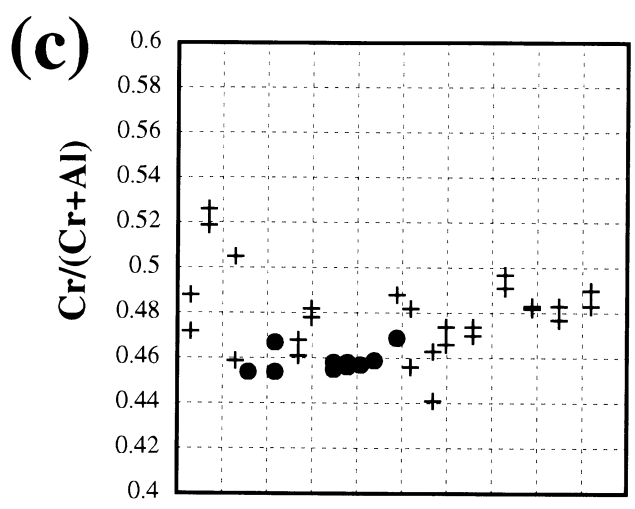
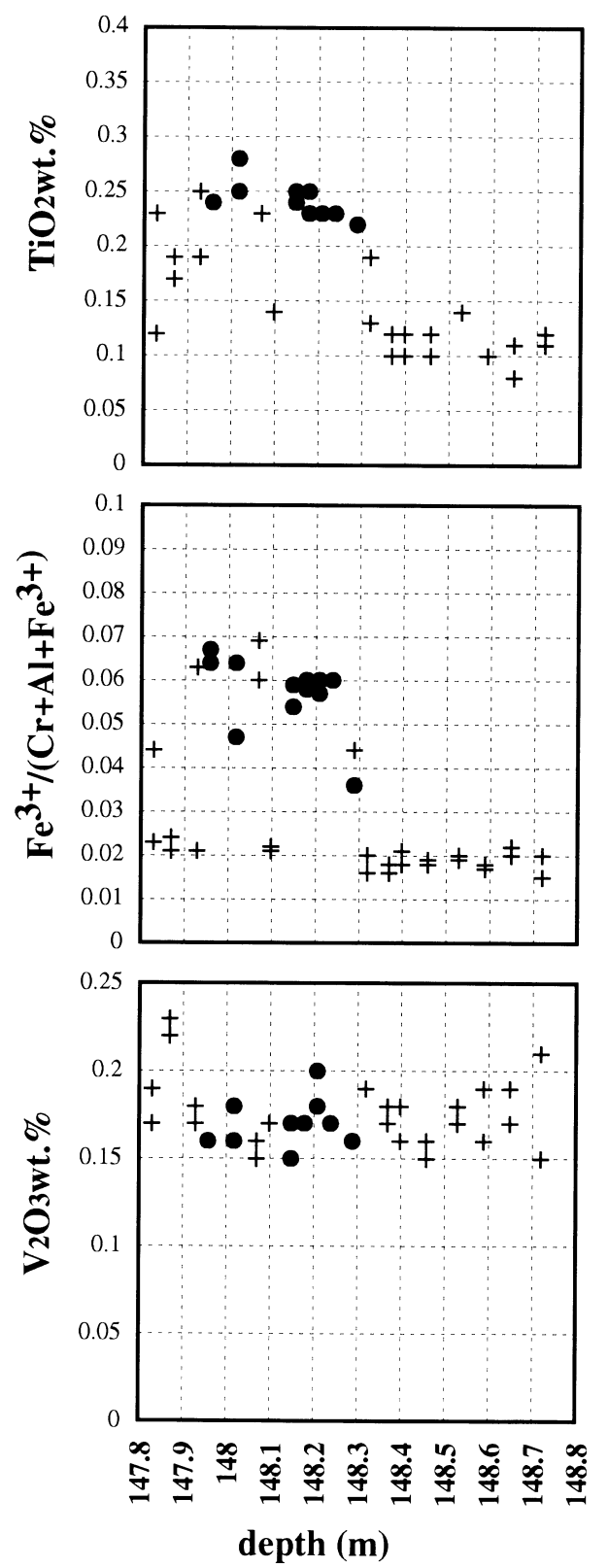

Figure 5. Chemical characteristics of chromian spinel in the one-meter interval (147.8 to $148.8 \mathrm{~m}$ ) from the drilled core 5MADO-2. (a)

Trivalent-cation $\left(\mathrm{Cr}-\mathrm{Al}-\mathrm{Fe}^{3+}\right)$ ratios of chromian spinel. (b) $\mathrm{Cr} /(\mathrm{Cr}+\mathrm{Al})$ atomic ratio vs. $\mathrm{V}_{2} \mathrm{O}_{3}$ wt\% of chromian spinel. (c) Downhole variation of $\mathrm{Cr} /(\mathrm{Cr}+\mathrm{Al})$ atomic ratio, $\mathrm{TiO}_{2} \mathrm{wt} \%, \mathrm{Fe}^{3+} /\left(\mathrm{Cr}+\mathrm{Al}+\mathrm{Fe}^{3+}\right)$ atomic ratio and $\mathrm{V}_{2} \mathrm{O}_{3}$ wt\% of spinel in the interval (147.8 to $148.8 \mathrm{~m})$. 
orthopyroxene break down took place is in harzburgite near the boundary between harzburgite and exotic melt. This part moved to the melt conduit and mixed with the exotic melt to form the secondary melt, enriched in $\mathrm{Si}$ and $\mathrm{Cr}$. Mixing of the secondary melt with subsequently supplied primitive melt, may make the spinel concentration along the wall harzburgite. Above process may have taken place almost simultaneity in this decimeterscale reaction.

It should be remarked that the morphology of spinel was modified during the chemical alteration by invading melt. The highly anhedral or even vermicular shape of chromian spinel associated with pyroxenes is characteristic of the harzburgite free from dunite association in the Tari-Misaka complex (Arai, 1980; Matsumoto and Arai, 2001). Anhedral or holly-leafshaped spinel closely associated with pyroxenes is also common in mantle peridotites with protogranular textures (Mercier and Nicolas, 1975; Nicolas et al., 1987). The origin of the spinel-pyroxene cluster is not yet clarified but has been interpreted as a former melt pocket produced by decompressional melting of garnet cluster in ancestral garnet peridotite (e.g., Nicolas et al., 1987). The initial anhedral chromian spinel in harzburgite was modified to be more euhedral during the reaction with exotic melt. The morphological change of spinel depends on the accessibility to the exotic melt that is able to release the surface energy of the mineral.

The morphological/chemical relations of chromian spinel between harzburgite and dunite have almost the same tendency, irrespective to the dimension of dunite and associated chromitite. The relations observed in the Wakamatsu mine area ( 0.2 to $0.3 \mathrm{~km}^{2}$ in plan) where large-scale dunite (up to $100 \mathrm{~m}$ thick) is associated with large chromitite pods (up to $20 \mathrm{~m}$ thick) (Matsumoto and Arai, 2001) are almost applicable to the small-scale dunite and adjacent harzburgite (within $5 \mathrm{~cm}$ ) in the present drill core (Figs. 3 and 4). This indicates that the mechanism of formation of dunite is basically the same for all the dunites, some of which are associated with large-scale chromitite formation in the Tari-Misaka complex. It is noteworthy, however, that the spinel from dunite and harzburgite free from large amount of chromitite, including the present drill cores, is generally lower in $\mathrm{TiO}_{2}, \mathrm{Cr} \#$ and $\mathrm{Fe}^{3+}$ than those associated with chromitites exposed in the Wakamatsu mine (Matsumoto and Arai, 1997).

Following the interpretation of Irvine $(1975,1977)$ for the genesis of stratiform chromitite, the podiform chromitites and associated peridotites (their dunite envelope and depleted harzburgite aureole) in the Sangun zone have been interpreted as the product of harzbur- gite/melt reaction (olivine precipitation combined with dissolution of orthopyroxene of the wall) and related magma mixing (Arai and Yurimoto, 1992, 1994; Matsumoto et al., 1997; Matsumoto and Arai, 1997). The variation of the $\mathrm{Cr} \#$ of spinel in dunite and associated harzburgite possibly reflect that the amount of orthopyroxene relative to the volume of exotic melt was different between the Wakamatsu mine area and the Mt. Hotokedaira area drilled in this study. Greater amounts of orthopyroxene were involved in the former than in the latter, provided that the involved melts were the same in composition, because mantle orthopyroxene has far higher $\mathrm{Cr} / \mathrm{Al}$ ratio than ordinary melts (cf. Arai and Abe, 1995; Arai and Yurimoto, 1995). The chemical composition of chromian spinel (e.g., $\mathrm{Cr} \#$ ) is dependent on both amount and chemical composition of orthopyroxene in wall harzburgite (e.g., Arai, 1997). It is suggested that smaller amount of orthopyroxene may be reacted with the exotic liquid in the southern part of the Tari-Misaka area and in other harzburgite-dominant complexes, where large chromitite pods are absent (Matsumoto and Arai, 2001). The small dunite veins in the drill cores in the present study may represent a peripheral part of the main melt conduit within harzburgite represented by large scale dunite with large chromitite pods of the Wakamatsu mine (Fig. 1). The formation of large chromitite pods possibly require both the participation of large amounts of orthopyroxene to the reaction, for supplying $\mathrm{Si}^{-}, \mathrm{Cr}-$ rich melt, and the sufficient room for melt mixing by turbulent current (cf. Paktunc, 1990). The turbulent current has been required for the formation of orbicular and nodular textures, characteristic of the podiform chromitite (cf. Lago et al., 1982).

\section{Summary and conclusions}

1. Harzburgite and dunite with decimeter-scale stratification from a one-meter interval of a drill core from the Tari-Misaka ultramafic complex are described in detail.

2. The morphological and chemical relations of chromian spinel in the dunite/harzburgite of the core are basically similar to those in the Wakamatsu mine area, except for the $\mathrm{Cr}$ \# of spinel, which is lower in the core. 3. The dunite is a product of the reaction between an exotic melt and harzburgite. Olivine crystals were precipitated with decomposition of orthopyroxene in harzburgite. The exotic melt modified both chemistry and morphology of spinel in the wall harzburgite.

4. The amount of orthopyroxene involved in the reaction to that of the exotic melt was probably smaller in the drill core than in the Wakamatsu mine area. This 
resulted the lower $\mathrm{Cr} \#$ of spinel in the drill-core rocks. It was concluded that the spinel chemistry is dependent on both amount and chemical composition of orthopyroxene in wall harzburgite.

5. Both the involvement of large amount of orthopyroxene in the reaction and turbulency of the melt current for mixing may be indispensable for the formation of podiform chromitite.

\section{Acknowledgements}

We are greatly indebted to MMAJ for accepting us to participate in one of the projects of MITI (MITI, 1994) and for approving of our analysis of the core samples and of our publishing the results. We thank Dr. A. Imai for his helping our microprobe analysis. We thank Mr. T. Yamane, Dr. H. Hirano, Mr. T. Miyauchi, Mr. K. Nakayama, Mr. H. Yamauchi, Dr. A. Ninomiya and Dr. N. Abe for their encouragement and hospitality to us.

\section{References}

Arai, S. (1975) Contact metamorphosed dunite-harzburgite complex in the Chugoku District, western Japan. Contributions to Mineralogy and Petrology, 52, 1-16.

Arai, S. (1980) Dunite-harzburgite-chromitite complexes as refractory residue in the Sangun-Yamaguchi zone, western Japan. Journal of Petrology, 21, 141-165.

Arai, S. (1997) Control of wall-rock composition on the formation of Podiform chromitites as a result of magma/ peridotite interaction. Resource Geology, 47, 177-187.

Arai, S. and Abe, N. (1995) Reaction of orthopyroxene in peridotite xenoliths with alkali basalt melt and its implication for genesis of alpine-type chromitite. American Mineralogists, 80, 1041-1047.

Arai, S. and Yurimoto, H. (1992) Origin of podiform chromitites from Southwest Japan as a melt-mantle interaction. Abstract of the 29th International Geological Congress, Kyoto, 1, 176.

Arai, S. and Yurimoto, H. (1994) Podiform chromitites of the Tari-Misaka ultramafic complex, southwestern Japan, as mantle-melt interaction products. Economic Geology, $89,1279-1288$.

Arai, S. and Yurimoto, H. (1995) Possible subarc origin of podiform chromitites. The Island Arc, 4, 104-111.

Arai, S., Inoue, T. and Oyama, T. (1988) Igneous petrology of the Ochiai-Hokubo complex, the Sangun zone, western Japan: a preliminary report. Journal of the Geological Society of Japan, 94, 91-102 (in Japanese with English abstract).

Hirano, H., Higashimoto, S. and Kamitani, M. (1987) Geology and chromite deposits of the Tari district, Tottori Prefecture. Bulletin of the Geological Survey of Japan, 29, 61-71 (in Japanese with English abstract).

Irvine, T.N. (1975) Crystallization sequences in the Muskox intrusion and other layered intrusions-(III). Origin of chromitite layers and similar deposits of other magmatic ores. Geochimica et Cosmochimica Acta, 39, 991-1021.

Irvine, T.N. (1977) Origin of chromitite layers in the Muskox intrusion and other stratiform intrusions: A new interpretation. Geology, 5, 273-277.

Ishiwatari, A. (1991) Time-space distribution and petrological diversity of Japanese ophiolites. In Ophiolite Genesis and Evolution of the Oceanic Lithosphere (Peters, Tj., Nicolas, A. and Coleman, R.G., Eds.),Kluwer, Dordrecht, 723-743.

Kelemen, P.B. (1990) Reaction between ultramafic rocks and fractionating basaltic magma I. Phase relations, the origin of calc-alkaline magma series, and the formation of discordant dunite. Journal of Petrology, 31, 51-98.

Lago, B.L., Rabinowicz, M. and Nicolas, A. (1982) Podiform chromitite ore bodies: A genetic model. Journal of Petrology, 23, 103-123.

Matsumoto, I. (1995) Degree of mantle-melt interaction and genesis of podiform chromitite in the dunite-harzburgitechromitite complexes of the Sangun zone, Southwest Japan. PhD thesis, pp. 99 Kanazawa University, Japan.

Matsumoto, I. and Arai, S. (1997) Characterization of chromian spinel as a tool of petrological exploration for podiform chromitite. Resource Geology, 47, 189-199.

Matsumoto, I. and Arai, S. (2001) Morphological and chemical variation of chromian spinel in dunite-harzburgite complexes from the Sangun zone (SW Japan): implications for mantle/melt reaction and chromitite formation processes. Mineralogy and Petrology (in press).

Matsumoto, I., Arai, S., Muraoka, H. and Yamauchi, H. (1995) Petrological characteristics of the dunite-harzburgitechromitite complexes of the Sangun zone, Southwest Japan. Journal of Mineralogy, Petrology and Economic Geology, 90, 13-26 (in Japanese with English abstract).

Matsumoto, I., Arai, S. and Yamauchi, H. (1997) High-Al podiform chromitites in dunite-harzburgite complexes of the Sangun zone, central Chugoku district, Southwest Japan. Journal of Asian Earth Sciences, 15, 295-302.

Mercier, J.-C. and Nicolas, A. (1975) Textures and fabrics of upper-mantle peridotites as illustrated by xenoliths from basalts. Journal of Petrology, 16, 454-487.

MITI (Japanese Ministry of International Trade and Industry) (1994) Report of Prospects for Mineral Resources of Rare Metals in the Dougoyama Area, pp. 67, Ministry of International Trade (in Japanese).

Nicolas, A., Lucazeau, F. and Baer, R. (1987) Peridotite xenoliths in Massif Central basalts, France: textural and geophysical evidence for asthenospheric diapirism. In Mantle Xenoliths (Nixon, P.H., Ed.), John Wiley \& Sons, New York, 563-574.

Paktunc, D.A. (1990) Origin of podiform chromite deposits by multistage melting, melt segregation and magma mixing in the upper mantle. Ore Geology Review, 5, 211-222.

Quick, J.E. (1981) The origin and significance of large, tabular dunite bodies in the Trinity peridotite, northern California. Contributions to Mineralogy and Petrology, $78,413-422$.

Manuscript received; 12 November, 1998

Manuscript accepted; 14 February, 2001 